\title{
Article \\ Design, Synthesis and Antifungal Activity of Stapled Aurein1.2 Peptides
}

\author{
Mengjun Zheng ${ }^{1,2}$, Ruina Wang ${ }^{2}$, Si Chen ${ }^{3}{ }^{(-)}$, Yan Zou ${ }^{2}$, Lan Yan ${ }^{2, *}$, Linjing Zhao ${ }^{1, *}$ and Xiang $\mathrm{Li}^{2, *}$ (1) \\ 1 College of Chemistry and Chemical Engineering, Shanghai University of Engineering Science, \\ Shanghai 201620, China; 17806170387@163.com \\ 2 School of Pharmacy, Naval Medical University, Shanghai 200433, China; 17621069104@163.com (R.W.); \\ zouyan@smmu.edu.cn (Y.Z.) \\ 3 School of Medicine, Shanghai University, Shanghai 200444, China; caroline-sisi-chen@hotmail.com \\ * Correspondence: ylansmmu@sina.com (L.Y.); linjingzhao2013@sina.com (L.Z.); xiangli@smmu.edu.cn (X.L.)
}

Citation: Zheng, M.; Wang, R.;

Chen, S.; Zou, Y.; Yan, L.; Zhao, L.;

$\mathrm{Li}, \mathrm{X}$. Design, Synthesis and

Antifungal Activity of Stapled

Aurein1.2 Peptides. Antibiotics 2021,

10, 956. https://doi.org/10.3390/

antibiotics 10080956

Academic Editors: Jean-Marc Sabatier and Zhijian Cao

Received: 7 July 2021

Accepted: 5 August 2021

Published: 9 August 2021

Publisher's Note: MDPI stays neutral with regard to jurisdictional claims in published maps and institutional affiliations.

Copyright: (c) 2021 by the authors. Licensee MDPI, Basel, Switzerland. This article is an open access article distributed under the terms and conditions of the Creative Commons Attribution (CC BY) license (https:// creativecommons.org/licenses/by/ $4.0 /)$.

\begin{abstract}
Aurein1.2 is a 13-residue antimicrobial peptide secreted by the Australian tree frog Litoria aurea. In order to improve its stabilities, the helical contents and corresponding biological activities of Aurein1.2 (a series of stapled analogues) were synthesized, and their potential antifungal activities were evaluated. Not surprisingly, the stapled Aurein1.2 peptides showed higher proteolytic stability and helicity than the linear counterpart. The minimum inhibitory concentration (MIC) of ten stapled peptides against six strains of common pathogenic fungi was determined by the microscale broth dilution method recommended by CLSI. Of them, Sau-1, Sau-2, Sau-5, and Sau-9 exhibited better inhibitory effects on the fungi than the linear peptide. These stapled Aurein1.2 peptides may serve as the leading compounds for further optimization and antifungal therapy.
\end{abstract}

Keywords: stapled peptide; AMP; aurein1.2; antifungal drugs

\section{Introduction}

Fungal disease is an infection of human skin, mucous membranes, subcutaneous tissue, and viscera caused by fungi, which severely threatens human life and health [1-4]. Candida is the most common pathogen causing opportunistic fungal infection in clinic, including the invasion of the mucosa and tissues of the host and local and systemic inflammatory reactions [5]. However, the limited availability of the present clinical antifungal drugs, including a narrow antimicrobial spectrum, severe drug resistance, and obvious side effects, bring huge challenges to antifungal therapy. Therefore, the discovery of a novel antifungal agent is urgent. Furthermore, the antimicrobial peptides (AMPs) exhibit moderate advantages compared to small molecules, such as fewer side effects and low toxicity. In addition, compared with proteins, peptides have a smaller volume, which can effectively reduce the manufacturing cost $[6,7]$.

AMPs are a class of small therapeutic peptides against microbial infections, which contain positively charged residues, like Arg or Lys, and hydrophobic residues. They possess potent activity against a wide range of Gram-negative and Gram-positive bacteria and showed low resistance compared with traditional antibiotics [8,9]. Aurein1.2 (GLFDIIKKIAESF-NH2) is an $\alpha$-helical AMP consisting of 13 amino-acid residues that were secreted by the Australian tree frog Litoria auream [10]. Aurein1.2 is a surface-acting membrane-disrupting peptide, and the mechanism of action of Aurein 1.2 may follow the carpet mechanism. Phe 3 and Phe13 may play an important role in the membranedisrupting activity [10]. Preliminary biological studies indicated that Aurein1.2 showed moderate potency against Fungi. Accordingly, Aurein1.2 could inhibit the growth of Candida albicans, Candida krusei, Candida tropicalis, Candida parapsilosis, Candida auris, and Candida glabrata [11]. Furthermore, alanine scanning of Aurein1.2 unveiled the structure- 
activity relationship of Aurein 1.2 and provided insights into the furthermore optimization of Aurein 1.2 [12].

However, Aurein1.2 showed the inevitable disadvantages of normal peptides, including low bioavailability, flexible conformation, and poor membrane permeability. The poor proteolytic stability would make the peptides lose their biologically relevant conformation when crossing membranes and entering the cell [13]. Its binding selectivity was low because of the original flexible conformation [14]. Therefore, it is necessary to constrain the helical conformation, enhance the proteolytic stability, and thus, increase the biological activities of Aurein1.2.

In recent years, an all-hydrocarbon peptide stapling strategy was developed by Verdine et al. and shown to be capable of reinforcing the helicity and stability of peptides and has been well used in peptide drug design [15-19]. In this study, to improve the performance of Aurein1.2, we designed a series of stapled Aurein1.2 peptides by using the all-hydrocarbon peptide stapling strategy, which can help Aurein1.2 improve its helical contents, proteolytic stability, and more importantly, antifungal properties.

\section{Results}

\subsection{Stapled Peptides Design and Synthesis}

We designed the hydrocarbon (stapled) analogues of Aurein1.2 to explore the influence on the stability, helicity, and antifungal activities of Aurein1.2 using all-hydrocarbon peptide stapling. Additionally, we choose i, with $\mathrm{i}+4$ as the stapling position and onehelix-space [20]. Accordingly, a series of stapled peptide analogues of Aurein1.2 were designed (Figure 1). Using conventional solid-phase peptide synthesis (SPPS) methods, we obtained a crude linear peptide precursor with a two-terminal olefin anchored residue [21]. Rink amide resin was used for solid-phase support, and the amine was protected with Fmoc (Figure 2) [22]. The assembled linear peptides, under the action of Grubb's first-generation catalyst, cyclized the peptide chain. Then peptides were cleaved from resin to get crude peptides. Crude peptides were purified by RP-HPLC. Finally, they were identified with high-performance liquid chromatography (HPLC) and high-resolution mass spectrometry (HR-MS) [23] (Supplementary Material).
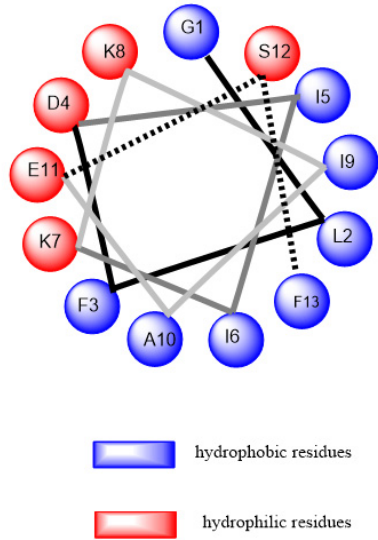

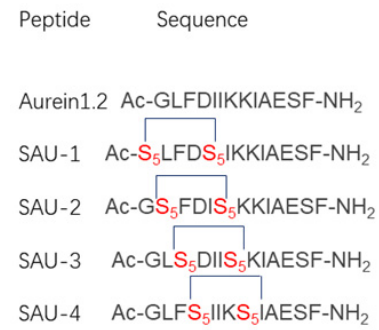

Figure 1. The sequences of Aurein1.2 and the stapled Aurein1.2 peptides. 


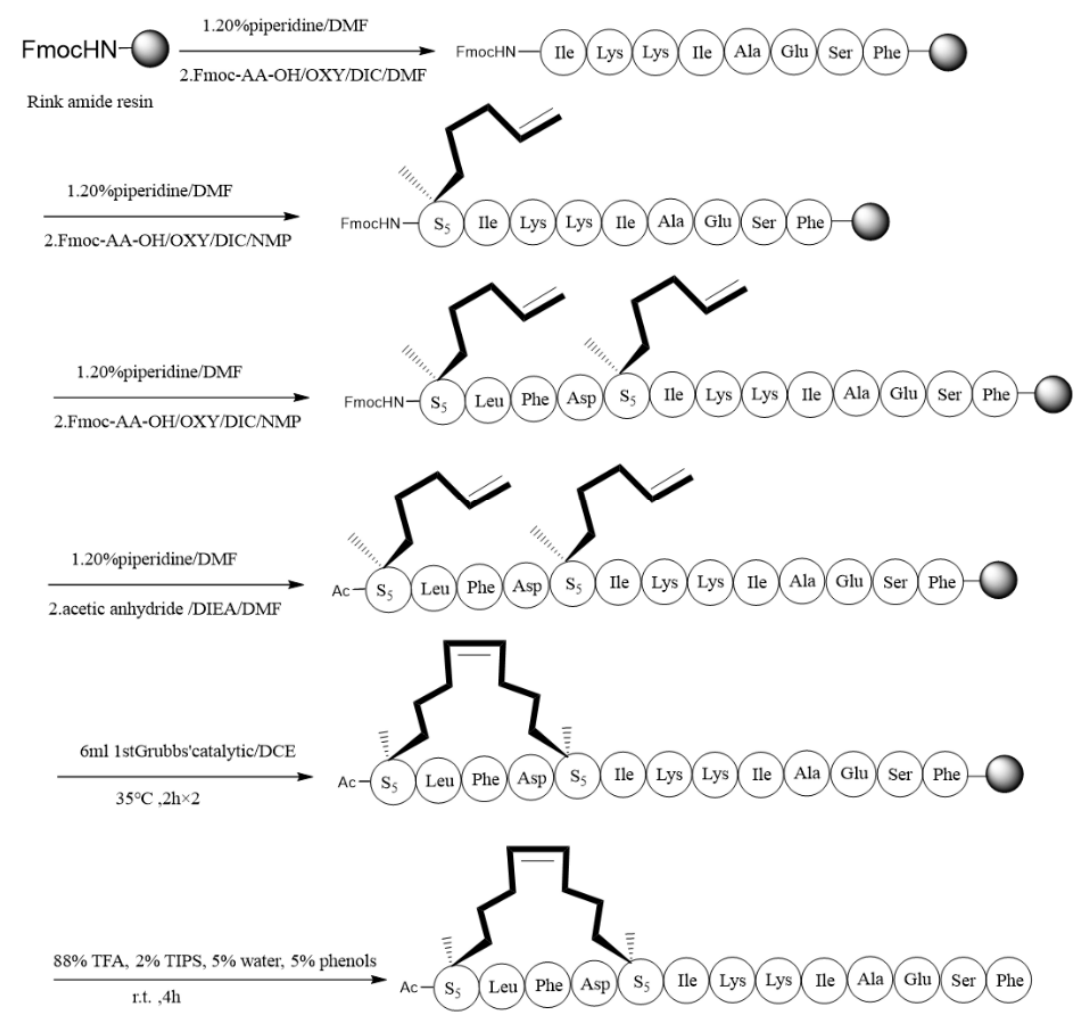

Figure 2. The synthetic route of stapled peptide Sau-1.

\subsection{Helicity Degree}

We use circular dichroism (CD) spectroscopy to probe the structural changes of Aurein1.2. According to the formula for calculating the helix reported in the previous relevant literature, we calculated the helicities of Aurein1.2 and the stapled peptides [24]. As Figure 3 shows, the helicities of Aurein 1.2 and the stapled peptides were measured. The CD data indicated that the helicity of Aurein 1.2 was $56.6 \%$, and the helicities of the stapled peptides were $60.2 \%, 52.5 \%, 72.3 \%, 73.5 \%, 61.0 \%, 49.9 \%, 65.0 \%, 83.1 \%$ and $67.8 \%$ for Sau-1, Sau-2, Sau-3, Sau-4, Sau-5, Sau-6, Sau-7, Sau-8 and Sau-9, respectively. These results indicate that the helical contents of most stapling peptides are higher than that of the linear peptide; that is, all-hydrocarbon stapling could enhance the helical contents of stapled analogues.

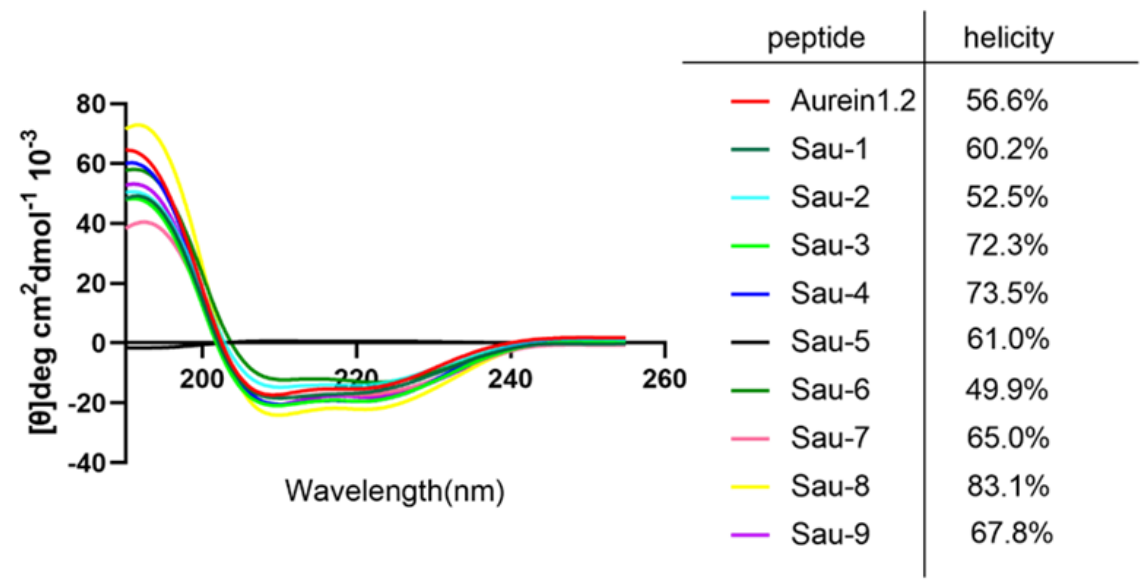

Figure 3. CD spectra of Aurein1.2 and its analogues. The peptides were dissolved in a solution of phosphate buffer and trifluoroethanol (7:3) and reached a concentration of $50 \mu \mathrm{M}$. The helicities of these peptides were calculated on the $[\theta]_{222}$. 


\subsection{Protease Stability Analysis}

Sau-1, Sau-2, Sau-5, and Sau-9 with relatively good activities were selected to study the proteolytic stability of the stapled peptides and compared with Aurein1.2. Their susceptibility toward chymotrypsin degradation was tested in pH 7.4 PBS buffer at room temperature, containing $2 \mathrm{mM}$ of $\mathrm{CaCl}_{2}$, and the percentages of remaining peptides were determined by HPLC. The C-terminal of the peptide hydrolytic site of chymotrypsin contains mainly aromatic amino acids, including phenylalanine (Phe), tryptophan (Trp), and lysine (Tyr), and has also been reported to hydrolyze Leu. As Figure 4 shows, Aurein1.2 was disintegrated almost completely by $4.5 \mathrm{~h}$. Interestingly, under the same conditions, the data demonstrated that both Sau-1, Sau-2, and Sau-5 remain relatively stable over time. Sau-9 was observed to be less stable than the other three stapled peptides and was slightly more stable than Aurein1.2. The results showed that most of the stapled peptides were more stable than the linear peptide. The corresponding HPLC charts for the determination of peptide residues are in the Supplementary Material.

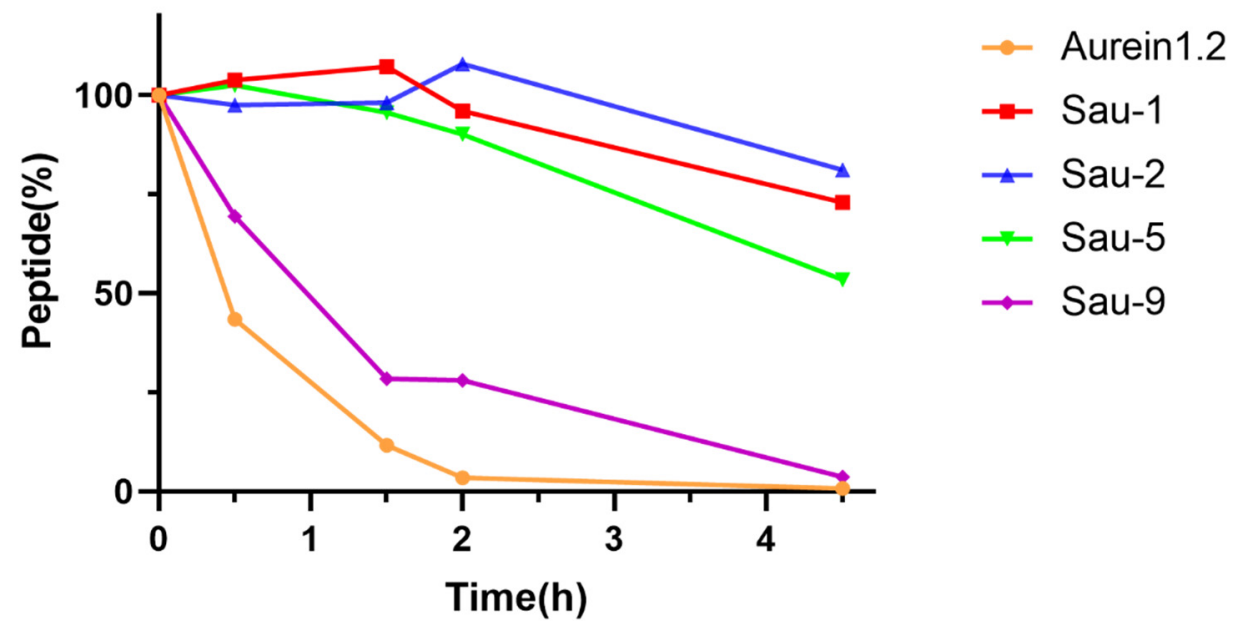

Figure 4. Proteolytic stability of Aurein1.2, Sau-1, Sau-2, Sau-5, and Sau-9. They were dissolved in chymotrypsin solution $\left(10 \mathrm{ng} / \mu \mathrm{L}, 50 \mathrm{mM}\right.$, containing $2 \mathrm{mM}$ of $\left.\mathrm{CaCl}_{2}, \mathrm{pH}=7.4\right)$. The percentages of the remaining peptides were monitored by HPLC.

\subsection{Determination of MIC for Candida Species}

The in vitro antifungal activities of the target peptides were evaluated according to protocols from the CLSI. The broth microdilution method was used to determine the minimum inhibitory concentration (MIC) of the target peptides in 96-well plates. Fluconazole was used as a reference drug. As shown in Table 1, Sau-1 inhibited the growth and reproduction of fluconazole-resistant clinical isolates of C. albicans 901 (MIC $32 \mu \mathrm{g} / \mathrm{mL}$ ) and C. parapsilosis ATCC22010 (MIC $128 \mu \mathrm{g} / \mathrm{mL}$ ). Sau-2 inhibited the fluconazole-resistant isolate C. tropicalis 895 with MIC of $16 \mu \mathrm{g} / \mathrm{mL}$. Sau-5 inhibited C. albicans SC5314 and C. tropicalis 895, both with MIC of $16 \mu \mathrm{g} / \mathrm{mL}$. Sau-9 can inhibit C. tropicalis 895 with an MIC of $32 \mu \mathrm{g} / \mathrm{mL}$. Our results indicated that the stapled peptides possessed antifungal activities. Moreover, the antifungal activities of some stapled Aurein1.2 peptides were higher than that of the linear peptide.

Table 1. Minimum inhibitory concentration $(\mathrm{MIC}, \mu \mathrm{g} / \mathrm{mL}$ ) of the target peptides against Candida isolates.

\begin{tabular}{|c|c|c|c|c|c|c|c|c|c|c|c|}
\hline \multirow[b]{2}{*}{ Peptide } & \multicolumn{3}{|c|}{ C. albicans } & \multicolumn{2}{|c|}{ C. tropicalis } & \multicolumn{2}{|c|}{ C. glabrata } & \multicolumn{2}{|c|}{ C. auris } & \multirow{2}{*}{$\begin{array}{c}\text { C. krusei } \\
\text { ATCC } \\
2340\end{array}$} & \multirow{2}{*}{$\begin{array}{c}\text { C. parapsilosis } \\
\text { ATCC } \\
22010\end{array}$} \\
\hline & SC5314 & 901 & 904 & $\begin{array}{l}\text { ATCC } \\
20026\end{array}$ & 895 & $\begin{array}{c}\text { ATCC } \\
1182\end{array}$ & 896 & 918 & 919 & & \\
\hline Sau-1 & $>64$ & 32 & $>128$ & $>128$ & $>128$ & $>128$ & $>128$ & $>128$ & $>128$ & $>128$ & 128 \\
\hline Sau-2 & $>64$ & $>128$ & $>128$ & $>128$ & 16 & $>128$ & 128 & $>128$ & $>128$ & $>128$ & $>128$ \\
\hline Sau-3 & $>64$ & $>128$ & $>128$ & $>128$ & $>128$ & $>128$ & $>128$ & $>128$ & $>128$ & $>128$ & $>128$ \\
\hline Sau-4 & $>64$ & $>128$ & $>128$ & $>128$ & $>128$ & $>128$ & $>128$ & $>128$ & $>128$ & $>128$ & $>128$ \\
\hline
\end{tabular}


Table 1. Cont.

\begin{tabular}{|c|c|c|c|c|c|c|c|c|c|c|c|}
\hline \multirow[b]{2}{*}{ Peptide } & \multicolumn{3}{|c|}{ C. albicans } & \multicolumn{2}{|c|}{ C. tropicalis } & \multicolumn{2}{|c|}{ C. glabrata } & \multicolumn{2}{|c|}{ C. auris } & \multirow{2}{*}{$\begin{array}{c}\text { C. krusei } \\
\text { ATCC } \\
2340\end{array}$} & \multirow{2}{*}{$\begin{array}{c}\text { C. parapsilosis } \\
\text { ATCC } \\
22010\end{array}$} \\
\hline & SC5314 & 901 & 904 & $\begin{array}{c}\text { ATCC } \\
20026\end{array}$ & 895 & $\begin{array}{c}\text { ATCC } \\
1182\end{array}$ & 896 & 918 & 919 & & \\
\hline Sau-5 & 16 & $>128$ & $>128$ & $>128$ & 16 & $>128$ & $>128$ & $>128$ & $>128$ & $>128$ & $>128$ \\
\hline Sau-6 & $>64$ & $>128$ & $>128$ & $>128$ & $>128$ & $>128$ & $>128$ & $>128$ & $>128$ & $>128$ & $>128$ \\
\hline Sau-7 & $>64$ & $>128$ & $>128$ & $>128$ & $>128$ & $>128$ & $>128$ & $>128$ & $>128$ & $>128$ & $>128$ \\
\hline Sau-8 & $>64$ & $>128$ & $>128$ & $>128$ & $>128$ & $>128$ & $>128$ & $>128$ & $>128$ & $>128$ & $>128$ \\
\hline Sau-9 & $>64$ & $>128$ & $>128$ & $>128$ & 32 & $>128$ & $>128$ & $>128$ & $>128$ & $>128$ & $>128$ \\
\hline Aurein1.2 & $>64$ & $>128$ & $>128$ & $>128$ & $>128$ & $>128$ & $>128$ & $>128$ & $>128$ & $>128$ & $>128$ \\
\hline Fluconazole & 0.5 & $>64$ & $>64$ & 1 & $>128$ & 2 & $>128$ & $>128$ & $>128$ & 64 & 1 \\
\hline
\end{tabular}

\section{Discussion}

In general, peptides can be modified by the methods of lipidation, glycosylation, and cyclization to enhance their protease resistance and improve their antibacterial activities [25]. In this case, we designed and synthesized a series of stapled Aurein1.2 peptides that exhibited improved proteolytic stability and higher helical contents than their linear counterparts. Importantly, the antifungal experiment indicated that these stapled peptides could effectively enhance the potency of Aurein1.2 towards some Candida species so as to provide the basis for the development of antifungal drugs in the future. Compared with Aurein1.2, Sau-1, Sau-2, Sau-5, and Sau-9 have slightly enhanced effects against some Candida strains. Specifically, Sau-1 has inhibitory effects against the fluconazole-resistant C. albicans isolate 901. Sau-2, Sau-5, and Sau-9 have higher effects than the fluconazole against the $C$. tropicalis isolate 895 . Overall, these stapled Aurein1.2 peptides may serve as the leading compounds for the future development of antifungal drugs.

It is not surprising that the antifungal activities of the stapled peptides are better than that of the linear peptide, and the helicity may be related to the antifungal activities. The potential correlation between the helical contents of the peptides and the biological activities has previously been shown [26], and a positive correlation does exist in this case. Therefore, it can be reasonably explained that the antifungal activities of stapled peptides were significantly improved compared with that of the linear peptide. Furthermore, a possible risk of Aurein1.2 peptide is its instability to enzymes, which could be improved through hydrocarbon stapling [26]. Sau-1, Sau-2, and Sau-5 obviously better resist the chymotrypsin hydrolysis than the linear counterpart. We speculate that the improved helical structures of stapled peptides reduce the leakage at the enzymatic hydrolysis site.

In summary, we report the first synthesis of a series of stapled peptides based on the Aurein1.2 sequence. The stapled peptides show higher proteolytic stability and helical contents (so as to enhance antifungal activities) relative to the linear peptide. Therefore, stapled Aurein1.2 peptides may be leading compounds for further optimization and antifungal therapy.

\section{Materials and Methods}

\subsection{Materials}

We use the Rink amide resin, bought in Nankai Hecheng Science \& Technology Co. Ltd. (Tianjin, China). We use all reagents and solvents which were purchased from Chemical Reagent Co. Ltd. (Shanghai, China), Qir biochem, or Titan Scientific Co. Ltd. (Shanghai, China), without further purification.

\subsection{HPLC}

The Waters and Agilent HPLC (high-performance liquid chromatography) systems were used for HPLC analysis and preparation. The analytical HPLC equipment used an analytical column $(X B$ ridge $C 18,5 \mu \mathrm{m}$ particle size, $150 \mathrm{~mm} \times 4.6 \mathrm{~mm}$, flow rate $1.0 \mathrm{~mL} / \mathrm{min}, 30^{\circ} \mathrm{C}$ ). The preparative column (YMC-Pack ODS-AQ C18, $10 \mu \mathrm{m}$ particle size, $250 \times 20 \mathrm{~mm}$, flow rate $30 \mathrm{~mL} / \mathrm{min}$ ) was also used; both used the same mobile phase 
system, which was composed of solution A ( $0.1 \%$ trifluoroacetic acid in water $)$ and solution $\mathrm{B}(0.1 \%$ trifluoroacetic acid in acetonitrile). They were monitored at $214 \mathrm{~nm}$, and $254 \mathrm{~nm}$ and the column temperature was $30^{\circ} \mathrm{C}$. For the analytical HPLC, the gradient followed: 0-5 $\mathrm{min}, 5-5 \% \mathrm{~B}$; 5-30 $\mathrm{min}, 5-65 \% \mathrm{~B}$; B. For the preparative HPLC, the gradient followed: 0-5 $\min , 25-25 \%$ B; 5-60 $\min , 25-45 \%$ B; 60-80 min, 80-80\% B.

\subsection{Stapled Peptides Synthesis}

We utilized the conventional solid-phase peptide synthesis (SPPS). Firstly, $333 \mathrm{mg}$ Rink Amide resin was soaked in dichloromethane (DCM) for $20 \mathrm{~min}$ at room temperature to induce swelling. Then, the Rink Amide resin was treated with Oxyme/piperidine/DMF $(71: 2: 4=\mathrm{m} / \mathrm{v} / \mathrm{v} 5 \mathrm{~min} \times 2)$ for the deprotection. Afterwards, we washed the resin with DMF, DCM, and DMF five times, five times and two times, respectively. To ensure the amino acid link to the resin, we added $0.5 \mathrm{mmol}$ Fmoc-AA-OH, $0.5 \mathrm{mmol}$ OXY, $0.5 \mathrm{mmol}$ $\mathrm{DIC}$, and about $7 \mathrm{~mL} \mathrm{NMP}$ to the resin. Then, the mixture was placed on a shaking table at $60{ }^{\circ} \mathrm{C}$. It needed $20 \mathrm{~min}$ to connect with the resin, followed by washing with DMF (5 times), DCM (5 times), and DMF (2 times). Each amino acid was detected with phenol and ninhydrin until there was no colour reaction. It started deprotection, followed by washing with DMF (5 times), DCM (5 times), and DMF (2 times). After deprotection, the next amino acid could be connected. All steps, including deprotecting, washing, coupling, and re-washing were needed to be repeated until all amino acid residues were linked to the resin. For particular amino acids, $S_{5}$ (2-amino-2-methylhept-6-enoic acid), we need to add 1.5 equiv. of the Fmoc-protected amino acid, and the required reaction time was $2 \mathrm{~h}$. Moreover, the amino acid located behind the $\mathrm{S}_{5}$ also needed $2 \mathrm{~h}$ to connect with the peptide. When the last amino acid was linked to the resin, DMF, DCM, and DMF were used to wash the resin five times, five times, and two times, respectively. Then the mixture of Oxyme, piperidine, and DMF $(71: 2: 4=\mathrm{m} / \mathrm{v} / \mathrm{v})$ was used to remove the Fmoc group from the N-terminus, followed by washing with DMF (five times), DCM (five times) and DMF (two times). The mixture of DIEA, acetic anhydride and DMF was added to the resin at room temperature for $20 \mathrm{~min}$ to react on an oscillating table. In the presence of Grubbs' first-generation catalyst and 1,2-dichloroethane (DCE) solvent, the assembled linear peptide cyclized the peptide chain. The solution of Grubbs' first-generation catalyst was dissolved in DCE, and the solution was added to the resin to react for $2 \mathrm{~h}$. After the first $2 \mathrm{~h}$, a fresh solution of Grubbs' first-generation catalyst was added to the resin for another $2 \mathrm{~h}$. The resin was washed with DMF (5 times), DCM (5 times) and DMF (2 times). The cocktail B regent (88\% TFA, 2\% TIPS, 5\% water, 5\% phenols) was added to the resin at room temperature for $4 \mathrm{~h}$ to make the cleavage of the peptide from the resin. Then ice ether was added to the solution, and the mixture was centrifuged at $3600 \mathrm{r} / \mathrm{min}$ for $3 \mathrm{~min}$. Then the supernatant was poured out, fresh diethyl ether was added and centrifuged again. This was repeated 3-4 times, then the supernatant was poured out, and the sediment was dried in nitrogen to get crude peptides.

\subsection{Circular Dichroism}

The linear peptide and the stapled Aurein1.2 peptides were dissolved to form a sample with a concentration of $50 \mu \mathrm{M}$. The solvent consists of phosphate-buffered solution and trifluoroethanol (7:3). We used a $1 \mathrm{~nm}$ quartz tube to obtain CD spectra on a Jasco-715 spectrophotometer at $20^{\circ} \mathrm{C}$. The measurement parameters were set up as follows: wavelength, 190-255 nm; speed, $20 \mathrm{~nm} \mathrm{~min}^{-1}$; step resolution, $1.0 \mathrm{~nm}$. And we accumulated the data twice. All spectral data were subtracted from the background. The curves were smoothed with standard parameters. The helicity of each peptide was calculated according to the equation in the literature [27].

\subsection{Chymotrypsin Digestion Assay}

Aurein1.2, Sau-1, Sau-2, Sau-5, and Sau-9, were dissolved in dimethyl sulfoxide to prepare a reserve solution with a concentration of $1 \mathrm{mM}$. Chymotrypsin was dissolved in 
PBS buffer (50 mM, containing $2 \mathrm{mM}$ of $\mathrm{CaCl}_{2}, \mathrm{pH}=7.4$ ) to obtain a final concentration of $10 \mathrm{ng} / \mu \mathrm{L}$. Then the $130 \mu \mathrm{L}$ peptide solutions were incubated with $910 \mu \mathrm{L}$ of chymotrypsin solution at room temperature. Then $130 \mu \mathrm{L}$ of digestion mixture was taken at $0,0.5,1.5,2$ or $4.5 \mathrm{~h}$, and then quenched with $50 \mu \mathrm{L}$ of hydrochloric acid $(1 \mathrm{mM})$. High-performance liquid chromatography (HPLC) was used to detect the residues of linear peptides and stapled Aurein1.2 peptides at $214 \mathrm{~nm}$ at a different time.

\subsection{Strains and Medium}

Clinical isolates of C. albicans SC5314, 901, 904, C. tropicalis ATCC20026 and clinical isolate 895, C. glabrata ATCC1182 and clinical isolate 896, C. krusei ATCC2340, and C. parapsilosis ATCC22010 are from the collection library in the Drug Discovery and Development Center, Naval Medical University, Shanghai, China. C. auris clinical isolates are provided by Linqi Wang (Institute of Microbiology, Chinese Academy of Sciences) and Changbin Chen (Institut Pasteur of Shanghai, Chinese Academy of Sciences). All strains were cultured in YPD (1\% yeast extract, $2 \%$ peptone, and $2 \%$ glucose) liquid medium overnight at $30^{\circ} \mathrm{C}$ with shaking at $220 \mathrm{rpm}$.

\subsection{Determination of MIC for Candida Species}

The MICs of chemicals against all strains were determined by the micro broth dilution method according to the Clinical and Laboratory Standards Institute (Wayne PA, Reference Method for Broth Dilution Antifungal Susceptibility Testing of yeasts, approved Standard M27-A3, 3 rd ed; Clinical and Laboratory Standards Institute (CLSI): USA, 2008). The initial concentration of fungal suspension in RPMI 1640 medium was 3-5 $510^{3}$ colonies forming unit (CFU)/mL, which was added to 96-well plates. Peptides were prepared in dimethyl sulfoxide (DMSO) with an initial stored concentration of $6.4 \mathrm{mg} / \mathrm{mL}$. Serial dilutions were made based on the CLSI M27 guide to obtaining the final concentrations ranging from 0.125 to $64 \mu \mathrm{g} / \mathrm{mL}$ for fluconazole and 0.25 to $128 \mu \mathrm{g} / \mathrm{mL}$ for peptides and fluconazole. The plates were incubated at $30{ }^{\circ} \mathrm{C}$ for $48 \mathrm{~h}$. Optical density was measured at $630 \mathrm{~nm}$, and background optical densities were subtracted from that of each well. The definition of MIC is the lowest concentration at which $80 \%$ of tested strains cannot grow.

Supplementary Materials: The following are available online at https: / www.mdpi.com/article / 10.3390/antibiotics10080956/s1, Figures S1-S10: HR-MS for compound Aurein1.2, SAU-1, SAU-2, SAU-3, SAU-4, SAU-5, SAU-6, SAU-7, SAU-8, and SAU-9. Figures S11-S20: Analytical HPLC trace for compound Aurein1.2, SAU-1, SAU-2, SAU-3, SAU-4, SAU-5, SAU-6, SAU-7, SAU-8, and SAU-9. Figures S21-S24: Analytical HPLC trace for the residual content of compound Aurein1.2, SAU-1, SAU-2, SAU-5, SAU-9. Figures S25-S28: The hydrolytic stability of Aurein1.2 and SAU1/SAU-2/SAU-5/SAU-9 was determined by high-performance liquid chromatography. Table S1: Electrospray MS data for peptides (positive mode).

Author Contributions: Conceptualization, X.L.; formal analysis, X.L.; investigation, M.Z., R.W., S.C., L.Y. and L.Z.; methodology, M.Z. and X.L.; resources, L.Y.; supervision, L.Y., L.Z. and X.L.; validation, M.Z., Y.Z. and X.L.; writing-original draft, M.Z. and R.W.; writing-review \& editing, X.L. All authors have read and agreed to the published version of the manuscript.

Funding: This work was supported by the National Key R\&D Program of China No. 2019YFC1711000 (to X.L.), the National Nature Science Foundation of China No. 21807112 (to X.L.), and the Shanghai Rising-Star Program (to X.L.).

Data Availability Statement: Data is contained within the article or Supplementary material.

Conflicts of Interest: The authors declare no conflict of interest. 


\section{References}

1. Nicola, A.M.; Albuquerque, P.; Paes, H.C.; Fernandes, L.; Costa, F.F.; Kioshima, E.S.; Abadio, A.K.R.; Bocca, A.L.; Felipe, M.S. Antifungal drugs: New insights in research \& development. Pharmacol. Ther. 2019, 195, 21-38.

2. Brown, G.D.; Denning, D.W.; Gow, N.A.; Levitz, S.M.; Netea, M.G.; White, T.C. Hidden killers: Human fungal infections. Sci. Transl. Med. 2012, 4, 165rv13. [CrossRef] [PubMed]

3. Brown, G.D.; Denning, D.W.; Levitz, S.M. Tackling Human Fungal Infections. Science 2012, 336, 647. [CrossRef] [PubMed]

4. Campoy, S.; Adrio, J.L. Antifungals. Biochem. Pharmacol. 2017, 133, 86-96. [CrossRef]

5. Lee, Y.; Puumala, E.; Robbins, N.; Cowen, L.E. Antifungal Drug Resistance: Molecular Mechanisms in Candida albicans and Beyond. Chem. Rev. 2021, 121, 3390-3411. [CrossRef] [PubMed]

6. Davenport, A.P.; Scully, C.C.G.; de Graaf, C.; Brown, A.J.H.; Maguire, J.J. Advances in therapeutic peptides targeting G proteincoupled receptors. Nat. Rev. Drug Discov. 2020, 19, 389-413. [CrossRef] [PubMed]

7. Lau, J.L.; Dunn, M.K. Therapeutic peptides: Historical perspectives, current development trends, and future directions. Bioorg. Med. Chem. 2018, 26, 2700-2707. [CrossRef] [PubMed]

8. Jenssen, H.; Hamill, P.; Hancock, R.E. Peptide antimicrobial agents. Clin. Microbiol. Rev. 2006, 19, 491-511. [CrossRef] [PubMed]

9. Li, W.; Separovic, F.; O'Brien-Simpson, N.M.; Wade, J.D. Chemically modified and conjugated antimicrobial peptides against superbugs. Chem. Soc. Rev. 2021, 50, 4932-4973. [CrossRef]

10. Shahmiri, M.; Enciso, M.; Mechler, A. Controls and constrains of the membrane disrupting action of Aurein 1.2. Sci. Rep. 2015, 5, 16378. [CrossRef]

11. Lorenzón, E.N.; Sanches, P.R.; Nogueira, L.G.; Bauab, T.M.; Cilli, E.M. Dimerization of aurein 1.2: Effects in structure, antimicrobial activity and aggregation of Cândida albicans cells. Amino Acids 2013, 44, 1521-1528. [CrossRef]

12. Migoń, D.; Jaśkiewicz, M.; Neubauer, D.; Bauer, M.; Sikorska, E.; Kamysz, E.; Kamysz, W. Alanine Scanning Studies of the Antimicrobial Peptide Aurein 1.2. Probiotics Antimicrob. Proteins 2019, 11, 1042-1054. [CrossRef]

13. Rezaei Araghi, R.; Keating, A.E. Designing helical peptide inhibitors of protein-protein interactions. Curr. Opin. Struct. Biol. 2016, 39, 27-38. [CrossRef]

14. Wu, Y.; Han, M.F.; Liu, C.; Liu, T.Y.; Feng, Y.F.; Zou, Y.; Li, B.; Liao, H.L. Design, synthesis, and antiproliferative activities of stapled melittin peptides. RSC Adv. 2017, 7, 17514-17518. [CrossRef]

15. Li, X.; Chen, S.; Zhang, W.D.; Hu, H.G. Stapled Helical Peptides Bearing Different Anchoring Residues. Chem. Rev. 2020, 120, 10079-10144. [CrossRef] [PubMed]

16. Li, X.; Zou, Y.; Hu, H.G. Different stapling-based peptide drug design:Mimicking $\alpha$-helix as inhibitors of protein-protein interaction. Chin. Chem. Lett. 2018, 29, 1088-1092. [CrossRef]

17. Liu, T.; Cong, W.; Ye, L.; Xu, X.; Liao, X.; Xie, G.; Cheng, Z.; Hu, H.; Li, X.; Liao, H. Rational design of stapled peptides targeting phosphorylated GSK3 $\beta$ for regulating osteoclast differentiation. RSC Adv. 2020, 10, 7758-7763. [CrossRef]

18. Walensky, L.D.; Bird, G.H. Hydrocarbon-Stapled Peptides: Principles, Practice, and Progress. J. Med. Chem. 2014, 57, 6275-6288. [CrossRef] [PubMed]

19. Wu, Y.; Li, Y.H.; Li, X.; Zou, Y.; Liao, H.L.; Liu, L.; Chen, Y.G.; Bierer, D.; Hu, H.G. A novel peptide stapling strategy enables the retention of ring-closing amino acid side chains for the Wnt/ $\beta$-catenin signalling pathway. Chem. Sci. 2017, 8, 7368-7373. [CrossRef]

20. Klein, M. Stabilized helical peptides: Overview of the technologies and its impact on drug discovery. Expert Opin. Drug Discov. 2017, 12, 1117-1125. [CrossRef]

21. Hood, C.A.; Fuentes, G.; Patel, H.; Page, K.; Menakuru, M.; Park, J.H. Fast conventional Fmoc solid-phase peptide synthesis with HCTU. J. Pept. Sci. 2008, 14, 97-101. [CrossRef] [PubMed]

22. Verdine, G.L.; Hilinski, G.J. Stapled peptides for intracellular drug targets. Methods Enzym. 2012, 503, 3-33. [CrossRef]

23. Liu, J.; Chen, S.; Chai, X.Y.; Gao, F.; Wang, C.; Tang, H.; Li, X.; Liu, Y.; Hu, H.G. Design, synthesis, and biological evaluation of stapled ascaphin-8 peptides. Bioorg. Med. Chem. 2021, 40, 116158. [CrossRef]

24. Wang, D.; Chen, K.; Kulp Iii, J.L.; Arora, P.S. Evaluation of biologically relevant short alpha-helices stabilized by a main-chain hydrogen-bond surrogate. J. Am. Chem. Soc. 2006, 128, 9248-9256. [CrossRef] [PubMed]

25. Madanchi, H.; Akbari, S.; Shabani, A.A.; Sardari, S.; Farmahini Farahani, Y.; Ghavami, G.; Ebrahimi Kiasari, R. Alignment-based design and synthesis of new antimicrobial Aurein-derived peptides with improved activity against Gram-negative bacteria and evaluation of their toxicity on human cells. Drug Dev. Res. 2019, 80, 162-170. [CrossRef]

26. Li, X.; Tolbert, W.D.; Hu, H.G.; Gohain, N.; Zou, Y.; Niu, F.; He, W.X.; Yuan, W.; Su, J.C.; Pazgier, M.; et al. Dithiocarbamate-inspired side chain stapling chemistry for peptide drug design. Chem. Sci. 2019, 10, 1522-1530. [CrossRef]

27. Cui, H.K.; Qing, J.; Guo, Y.; Wang, Y.J.; Cui, L.J.; He, T.H.; Zhang, L.; Liu, L. Stapled peptide-based membrane fusion inhibitors of hepatitis C virus. Bioorg. Med. Chem. 2013, 21, 3547-3554. [CrossRef] 